\title{
Health Impact of Pesticide Using Method at Sprayed Worker Farmer in Sumber Mufakat Village, Karo
}

\author{
Eka Lestari Mahyuni ${ }^{1}$, Muhammad Makmur Sinaga ${ }^{2}$ \\ ${ }^{1,2}$ Occupational Safety and Health Department, University of Sumatera Utara, Indonesia \\ eka mahyuni@ymail.com \\ makmur_sinaga@ymail.com
}

\begin{abstract}
Pesticide using was a problem concern specialized in safety and health aspect. Missing at work method and not in procedure could increasing of health problem specialize to occupational accident and occupational disease.

The purpose of this research was to know the health impact of pesticide from pesticide using method at sprayed worker farmer in Sumber Mufakat village Kabanjahe Karo.

This is an analytical survey with cross sectional design. Population are all sprayed worker farmer at Sumber Mufakat village amount 125 people and with using Lameshow formula found the sample size in 55 people. Data was collect by interview and direct observation by using documentation and questionnaire. The data will analyze by using chi-square test. The potential method that influence the health impact was in mixing the pesticide where the sprayed worker farmer has direct contact in using the pesticide. The second potential method was in sprayed the pesticide which is always face on the wind blows that bring the pesticide to exposure the sprayed worker farmer. The health impact from pesticide using like dizzy, headache, eyes irritation, musculoskeletal disorder, nausea and fatique. The chi-square test found that $p=0.00$ means there is a significant relation between the pesticide using method with health impact of sprayed worker farmer.

This research conclude that there was a significant relation between pesticide using method with health impact. Recommended for the sprayed worker farmer to prevent themselves by using safety equipment to avoid the direct exposure from pesticide.
\end{abstract}

Keywords - pesticide, sprayed worker farmer, health impact

\section{INTRODUCTION}

Pesticide using was a problem concern specialized in safety and health aspect. Occupational safety and health of farmers can be observed along the farmers worked as laborers on a farm or plantation. On the other hand the farmers that managing their land either personally or lease neglected and unnoticed, especially for aspects of occupational safety and health. The highest hazard of farm life is when the farmers use the pesticides to maintain or increase their production of agriculture [1].

The use of pesticides is a problem that needs to be considered, especially in the aspects of safety and health. In the plantation sector, the pesticide is the one of factor that has quite serious danger due to the effect of directly or indirectly as causing the death. Starting from the exposed directly or indirectly like spattered, spill, swallowing even cause food poisoning that can impact chronic or acute.

Most of work farmers in Indonesia knows the dangers of pesticides, but they do not care about the consequences. Many work farmers who work using pesticides without using the safety equipment such as masks, hats, clothes that cover the body, and others. Even worse when reminded to use personal protective equipment, the farmer proudly mentions that they are immune to the pesticide odor that stung. Work farmers generally assumed that the use of personal protective equipment when handling pesticides is impractical and considered inconvenient. If the tool is not used, then these pesticides could be into the body through the skin and the respiratory tract [2].

Missing at work method and not in procedure could increasing of health problem specialize to occupational accident and occupational disease. Based on the primary survey, the work farmers never using the safety equipment when they do their activities. Their opinion for the equipment that if they are using the safety equipment, it will give the feeling like uncomfort, hot and difficult to move. The work farmers also pay less attention for the wind direction and said that it's impossible to do because they have to spray the wide land each day.

\section{AIM OF THE RESEARCH}

The purpose of this research was to know the health impact of pesticide from pesticide using method at sprayed worker farmer in Sumber Mufakat village Kabanjahe Karo. 


\section{METHODS}

This is an analytical survey with cross sectional design to find out the health impact from pesticides sprayed work farmers method. The study was conducted in Sumber Mufakat Kabanjahe District of Karo. The research was conducted from FebruaryMay 2016. Population are all productive sprayed worker farmer at Sumber Mufakat village amount 125 people and with using Lameshow formula found the sample size in 55 people. Data was collect by interview and direct observation by using documentation and questionnaire. The data will analyze by using chi-square test.

TABLE I

Collection AND Measurement Data Methods

\begin{tabular}{|l|l|l|l|l|}
\hline Variable & $\begin{array}{l}\text { Measure } \\
\text { Method }\end{array}$ & Measurement & Scale & Result \\
\hline $\begin{array}{l}\text { Health } \\
\text { Impact }\end{array}$ & Interview & $\begin{array}{l}\text { Health } \\
\text { complain }\end{array}$ & Categoric & $\begin{array}{l}\text { 1. Complaint } \\
\text { 2. No } \\
\text { complain }\end{array}$ \\
\hline $\begin{array}{l}\text { Pesticides } \\
\text { using } \\
\text { method }\end{array}$ & $\begin{array}{l}\text { Observation } \\
\text { Interview }\end{array}$ & $\begin{array}{l}\text { Photo/Video } \\
\text { camera }\end{array}$ & Categoric & $\begin{array}{l}\text { 1. Hazard (+) } \\
\text { 2. Hazard (-) }\end{array}$ \\
\hline
\end{tabular}

\section{RESULTS AND DISCUSSION}

\section{A. Occupational Safety and Health Hazards in Pesticide Using}

Based on the field observations during the research, it showed that all work farmers average has an holticultura plant like chilli, tomato, cabbage, peterseli, cucumber, potatoes, carrot, beans, and pokchoy vegetables. Some of them also has the high plants like, flowers, coffe, and orange. The pattern of work and working methods in homogeneous work process of pesticides sprayed work farmers. Starting from weeding plants, mixing pesticides, until spraying of pesticides. Work farmers undertake the work process without using of Personal Protective Equipment (PPE). Beside that, not just only one pesticide using in one plant, but it makes some pesticides for one plant. The other hand, the land not just fill in one type of plant but almost one land it fill in three or more kind of plant. For example include in one land it has a tomato, chilli, cabbage and bean or there is flower, cabbage and tomato.

This condition will bring the most potential hazards for the farmers. With more kinds of plants, it will make the farmers using more kind of pesticides to protect their plant. Then it means the hazards of pesticides exposure are high. In other hand, the farmers always in direct contact with pesticides, cause they are not using personal protective equipment (PPE).Work farmers simply using boots and long-sleeved clothing from shirts or T-shirts, sometimes equipped with a sweater and hat mountain due to the cold climate of mountains.

During spraying the work farmer does not follow the direction of the wind so they often splashed with the pesticides during spraying. Parts of the body often affected are the eyes, hands and feet. In general, farmers have their own techniques for spraying pesticides and this does not close the possibility of exposure of pesticides to work farmers that can increase the risk of pesticide poisoning. It is shown from complaints from farmers spraying pesticides is red and painful eyes, nausea, dizziness, headache, squash and weak in the knees.

This pain can escalate and get worse that the effects of pesticide residues on human health is that it can interfere with the metabolism of steroids, impair thyroid function, effect on spermatogenesis; disruption of the endocrine hormone system (reproductive hormones) or better known as EDS (Endocrine Disrupting Pesticides), in addition to stimulating the onset of cancer [4].

Research conducted journal article in [5] stated that the selection of the wrong wind direction can affect the levels of cholinesterase enzyme when spraying with a downwind or any direction then the pesticides will be carried by the wind and inhaled especially if PPE incomplete. So, by spraying with the direction of the wind will reduce the risk of pesticide poisoning due to inhalation and the eyes and skin.

\section{B. Weeding Plants Before Spraying Pesticides and Health Impact of Pesticides Sprayed Work Farmers.}

Weeding plants are useful to give the good growed of plants. In the usually activites the farmers do the weeding plant in manual work and looks in not ergonomic posture like squatting, bending, relying on both knees or feet. During the process of weeding, work farmers usually clean up and remove the grass or weeds that disrupt and loosen the soil [5].

With an area of land and low crop species make work farmers feel pain in the knees (35\%), legs $(22 \%)$, legs $(33 \%)$, waist (6\%) and neck (4\%). This squat work posture has the same effect as the impact 
is not ergonomic posture. Poor posture while working and lasts longer cause muscle burden and negative effects on health [6]. Beside that, the farmers fell fatique and dizzy or headache because the sunny in direct contact. To avoid that, some farmers do weeding plant in early morning or noon.

\section{Pesticides Mixing Method and Health Impact of Pesticides Sprayed Work Farmers}

Mixing pesticides method usually do in the land. The farmers bring the pesticides from their house with one pail, then bring of them to the embankment for reach the water for mixing it. From the research, some farmer not attention but the dose. They are using the instuition or feeling to measuring the container. Actually, in one mixing container, it has two or three types of pesticides and all of that in manual process and looks it is potential has a direct contact with the body. In means in mixing pesticide method with directly contact has the risk of exposure which very high. Farmer behavior when mixing of pesticide is dangerous enough when viewed from the occupational safety and health aspect. Among work farmers without PPE, sometimes also bite the unwrapping the packaging of pesticides if it is difficult when opened by hand. The dose used to be mixed as well not use the measuring spoon but poured granted in accordance habit.

Based on the interview farmers stated that the doses of pesticides used frequently added and not in accordance with specified doses. The mixing is done approximately 5-15 minutes by opening pesticide containers, taking water, then mix the pesticide and water and stirring the mixture. Health impact that shows in this method are dizzy, eye irritation, rash in hand, allergy, nausea cause the smell and musculosceletal complaint.

D. Method of Displacement and Removal of Spray Pumps and Health Impact of Pesticides Sprayed Work Farmers

Judging from the ergonomic aspect, this process shows the dangers of manual handling risks are quite high. After mixing the farmers will move the resulting mixture into a spray pump. Working posture formed in this process the average doing with bent posture while lifting a bucket or barrel containing a pesticide mixture to be poured into the spray pump. The risk of accidents and spillage of pesticides are quite common due to the width of the container which is not in accordance with the magnitude of the width of the mouth of the spray pump. Spray pumps are also often placed on the ground so that the agricultural land ergonomic postures often occur as squatting and bending.

Some complaint based on this method actually more in musculosceletal complaint. The farmers feels pain in their arm (40\%), shoulder (47\%), and finger $(13 \%)$. This complaint is felt for raising mix and hold the outskirts of the container when poured pesticide into the pump. Pain in the shoulder after pouring the work farmers perceived as directly holding the pump to be used. Farmers feel the pain and strained muscles for lifting and moving the pesticide mixture that will be used.

Working attitude one of the causes of fatigue and muscle pain complaints which are often unrecognized by sufferers. Especially working attitude has become one's habits such as sitting, standing and bending could cause the fatigue, muscle tension and eventually pain. Besides the bones become misaligned, the muscles, and the segment will be interested harder of ligament [7].

In this method, some time the farmer has the habit to inhale the pump hole before using that to check the function of pumps. It looks usually but the risk to exposure of pesticide by oral is very high. The other complaint in this process are not found in clearly. But the reseach assume that probably the little pesticides are swallowed accidentally. It needs to check the cholinesterase enzym activites to complete the health impact case.

\section{E. Spraying Pesticide Method and Health Impact of Pesticides Sprayed Work Farmers}

Spraying pesticides by work farmers are doing at least 1-2 hours and a maximum of 6-7 hours a day dependent on the land and plant species were sprayed. The average farmer spraying alternating manner in accordance with the arrangement of agricultural crops, so that in this process the farmers do not pay attention to the wind direction. Therefore the frequent complaint splashed into the eyes or pesticides evaporate and make eye sore into a complaint that is often felt by sprayed work farmers in this village.

The other health impact in this process is musculosceletal complaint because all of work 
farmers still use a pump carrying, causing pain in their neck, shoulders and hands, especially the right hand $(100 \%)$. Both of these body parts are often used in the spraying process and become ill because of land to be sprayed started from 2 ha to 5 ha. Work farmers will continue to run until the spraying is completed.

Research on the agricultural sector in 2007 [8] shows that farmers and agricultural workers are at risk of fatigue in the neck and shoulders that comes from the types of activities undertaken such as lifting, nodded and spraying. In line with research in the agricultural sector in the United Kingdom that during the spraying activities with the manual handling of spray pump and manual handling activities of other non-fatal injuries can cause the most.

\section{F. The Relation Between Pesticide Using Method and Health Impact}

All of pesticide using method at work farmer in Sumber Mufakat village are looks dangerous and has a risk potential hazards. It looks from the unsafe activities and un-procedure using. Although some farmers feels the health impact is not bring the serious impact cause the effect will be lose when they are clean up all pesticide, but the serious health impact could be happens in time periodic.

The potential method that influence the health impact was in mixing the pesticide where the sprayed worker farmer has direct contact in using the pesticide. The second potential method was in sprayed the pesticide which is always face on the wind blows that bring the pesticide to exposure the sprayed worker farmer. The health impact from pesticide using like dizzy, headache, eyes irritation, musculoskeletal disorder, nausea and fatique.

The relation between pesticide using method with health impact is significant, showed from chi-square test $p$-value $=0,00$ (showed at table 1$)$. It means, the unsafe method when using the pesticides has a relation with health impact. So many factors that has to know the cause of health impact from pesticides using for example the type of pesticide. Many pesticides has a different effect for the user. It could be give the reversibble toxic effect or irreversible toxic effect. To the safety and health program it needs to looks the cholinesterase enzym activities to complete the prognosis of health impact from this research.

TABLE II

RELATION BETWEEN PESTICIDE USING METHOD WITH HEALTH IMPACT OF WORK FARMER AT SUMBER MUFAKAT VILLAGE.

\begin{tabular}{|l|c|c|c|c|c|c|c|}
\hline \multirow{2}{*}{$\begin{array}{c}\text { Pesticide } \\
\text { Using Method }\end{array}$} & \multicolumn{4}{|c|}{$\begin{array}{c}\text { Health Impact } \\
\text { Complaint } \\
(-)\end{array}$} & $\begin{array}{c}\text { Complaint } \\
(+)\end{array}$ & \multicolumn{3}{c|}{ Total } & \multirow{2}{*}{ P-value } \\
\cline { 2 - 7 } & $\mathrm{n}$ & $\%$ & $\mathrm{n}$ & $\%$ & $\mathrm{n}$ & $\%$ & \\
\hline Hazard (+) & 15 & 57,7 & 26 & 42,3 & 41 & 100 & \multirow{2}{*}{0.00} \\
\hline No Hazard (-) & 8 & 57,1 & 6 & 42,9 & 14 & 100 & \\
\hline
\end{tabular}

\section{CONCLUSION}

Occupational safety and health hazards happens at all process of pesticides using and dominant at weeding plants process, mixing the pesticides specially of excessive dosage and spraying of pesticides method, diplacement and removal the pesticides pumps and spraying method that usually no attention the wind direction. The work farmers complaint of irritation from their eyes, rash and dizzies, headache, nausea, allergy and musculosceletal complaints, when they was exposure by pesticides in direct contact .

To recommended that specialized for the work farmers that has a wide land (more than $3 \mathrm{ha}$ ) could change their pump with using the portable machine of pesticides sprayed. Most of important the work farmer have to do streching activities to eliminate the fatigue or pain at part of body in five minutes during their work. For the village it's important to create the controlling pesticides using organization and collaboration with Health Institution to check the cholinesterase enzyme for pesticides poisoning prevention.

\section{ACKNOWLEDGEMENT}

We said thankfully for Mr.Tarigan that very helpful to manage and completed of this research and his collaboration with related organization and farmers to collect and giving their time to make this research success. Researchers know that Sinabung eruptions made the team has to clearly arrange the time for this research. So many contributes of the pesticide sprayed work farmers to finishing this research in completely. Sincerely for Directorate of Research, Science and Technologies that helpful from the budget from this research. 


\section{REFERENCE}

[1] Arikunto, 2009, Metode Penelitian Kualitatif, Rineka Cipta

[2] Kotowski S.E, 2007 Understanding the Ergonomic Risk for Musculosceletal Disorders in the United States Agricultural Sector (online) http://ncbi.nlm.nih.gov/m/PubMed/17506508 Am J Ind Med July 2007 50:501-511 access date: 13 Maret 2015

[3] Prasetya E, wibawa A, A, Enggarwati, 2010, Hubungan Faktor-faktor paparan Pestisida terhadap kadar Cholinesterase pada Petani Penyemprot Tembakau di desa Karangjati, Kabupaten Ngawi (online) Jurnal Fakultas Ilmu Kesehatan, Universitas Setiabudi, Surakarta

[4] Siwiendrayanti, Arum, 2011, Keterlibatan Dalam Aktivitas Pertanian Dan Keluhan Kesehatan Wanita Usia Subur, Jurnal KEMAS, 7 (1); 73-82

[5] Solomon C, 2002 Accidental Injuries in Agriculture in the UK (online) http://ncbi.nlm.nih.gov/m/PubMed/12488516, Occupational medicine, London, December 2002 52:461-466

[6] Sundari , K,N, 2010 Tinjauan Ergonomi terhadap Sikap Kerja Petani di Banjar Tengah, Desa Peguyangan, Denpasar Utara. Metris: Jurnal Mesin, Elektro, Industri dan Sains, II(2):71-76

[7] Titisria. Makalah pestisida dalam rumah tangga [artikel di internet]. 2011 [diunduh 02 Oktober 2014]. Tersedia dari : http://titisria.blogspot.com.

[8] Widyastoeti, R.D, 2009, Analisa Pengaruh Aktivitas Kerja dan Beban Angkat terhadap Kelelahan Muskuloskeletal (online) Gema Teknik Vol 2: 28-29 diakses tanggal 27 Juni 2015 